\title{
Combined impact of sewage and industrial effluent on Rice (Oryza sativa) in Marh Block, Jammu (J\&K)
}

\author{
Sharma Deepika a and Rampal Raj Kumar
}

Received: 25.02 .2018

Revised: 28.04.2018

Accepted: 14.07.2018

\begin{abstract}
Agricultural use of domestic waste water is a cheap way of its disposal as it is rich in organic materials and plant nutrients $(\mathrm{N}, \mathrm{P}, \mathrm{K}, \mathrm{Ca}, \mathrm{Mn}$ and $\mathrm{Zn}$ ). Use of domestic waste water in agriculture may contribute considerable to alleviate the pressure in using fresh water resources. The present study has been carried out to study the effect of combined sewage and industrial effluent on rice crop. The observations revealed insignificant $(p>0.05)$ stimulatory effect on shoot length, root length, no. of nodes, no. of leaves, no. of grains on panicle, dry wt. of whole plant, dry wt. of panicle and dry wt. of grains during Ist year study period and root length, no. of nodes, no. of leaves, dry wt. of whole plant and avg. wt. of grains during $2^{\text {nd }}$ year study period. Whereas significant stimulatory effect was observed on avg. wt. of grains during $1^{\text {st }}$ year study period and shoot length, no. of grains on panicle, dry wt. of panicle, dry wt. of grains during $2^{\text {nd }}$ year study period.
\end{abstract}

Key words: Combined Sewage and industrial effluent, irrigation, Rice crop, growth and yield.

\section{Introduction}

Urban centres discharge waste water into the water bodies and is used for irrigation in the agricultural fields. Sewage is the major sources of organic pollution in fresh water bodies (Bhutiani and Ahamad, 2018). Sewage includes domestic, hospital and small scale industrial wastes operating under municipal area. All the cities and towns of India are lacking proper sewage treatment facilities and so disposal of waste water is one of the major problems (Bhutiani et al., 2016). Increasing reuse of treated effluent in agriculture serves goals such as promoting sustainable agriculture preserving scare water resources and maintaining environmental quality. Moreover irrigation with waste water may reduce purification levels and fertilization costs because soil and crops serve as bio-filters while waste water contains nutrients. . Domestic waste water has been reported to increase crop yield. (Pathak et al., 1998, Pathak et al., 1999). In present study an attempt has been made to study the impact of combined sewage and industrial effluents on growth and yield of Rice (Oryza

\section{Author's Address}

${ }^{1}$ GDC Jindrah, Jammu

${ }^{2}$ Department of Environmental Sciences University of Jammu, Jammu

E-mail.: rajkrampal@gmail.com sativa) in Marh Block, Jammu (J\&K).

\section{Material and Method}

The study area for the purpose of investigation was divided into two sites:-

Site 1: Reference Site (Parwah):- At this site rice is irrigated with ground water (Tube-well) having no contaminants of combined industrial and sewage effluent.

Site 2: Polluted Site (Dai Chak): At this site rice is irrigated with combined sewage and industrial effluent.

During sampling 30 plants from each site were uprooted randomly along with roots from the ground at the time of harvesting and were collected in Polythene bags. The stem and roots were properly washed with water so as to remove soil attached to them and then were air dried for 2-3 hrs. Shoot and root length of each plant was measured using thread and geometric scale. No. of leaves, nodes and total no. of grains attached to the each plant were also counted numerically. The plant samples were oven dried for $24 \mathrm{hrs}$. at $65^{\circ} \mathrm{C}$ temperature. The dry weight of each of whole plant (in gm), dry weight of panicle (in $\mathrm{mg}$ ), and dry weight of all the grains of panicle of each of 30 
Sharma and Rampal

Table 1. Impact of combined industrial and sewage effluents on Rice

\begin{tabular}{|l|l|l|l|l|l|}
\hline \multirow{2}{*}{ S.No. } & \multirow{3}{*}{ Parameters } & \multicolumn{2}{|l|}{ Ist Year (2015) } & \multicolumn{2}{l|}{$\mathbf{2}^{\text {nd }}$ Year (2016) } \\
\cline { 3 - 6 } & Reference Site & Polluted Site & Reference Site & Polluted Site \\
\hline $\mathbf{1}$ & Shoot length(cm) & $\begin{array}{l}80.25 \pm 9.7 \\
(60-96)\end{array}$ & $\begin{array}{l}81.4 \pm 11.04 \\
(67-101)\end{array}$ & $\begin{array}{l}76.5 \pm 12.6 \\
(60-98)\end{array}$ & $\begin{array}{l}85.2 \pm 13.7 \\
(56-104)\end{array}$ \\
\hline $\mathbf{2}$ & Root length(cm) & $\begin{array}{l}13.3 \pm 4.2 \\
(9-21)\end{array}$ & $\begin{array}{l}14.9 \pm 3.2 \\
(10-21)\end{array}$ & $\begin{array}{l}13.4 \pm 3.6 \\
(8-19)\end{array}$ & $\begin{array}{l}15.4 \pm 5.2 \\
(8.5-26)\end{array}$ \\
\hline $\mathbf{3}$ & No. of Nodes & $\begin{array}{l}5.3 \pm 0.8 \\
(4-6)\end{array}$ & $\begin{array}{l}5.45 \pm 0.6 \\
(4-6)\end{array}$ & $\begin{array}{l}5.2 \pm 0.6 \\
(4-6)\end{array}$ & $\begin{array}{l}5.3 \pm 0.6 \\
(4-6)\end{array}$ \\
\hline $\mathbf{4}$ & No. of leaves & $\begin{array}{l}4.7 \pm 0.55 \\
(4-6)\end{array}$ & $\begin{array}{l}4.85 \pm 0.5 \\
(4-6)\end{array}$ & $\begin{array}{l}4.7 \pm 1.06 \\
(2-6)\end{array}$ & $\begin{array}{l}4.75 \pm 0.7 \\
(4-6)\end{array}$ \\
\hline $\mathbf{5}$ & $\begin{array}{l}\text { Total no. of grains } \\
\text { on the panicle }\end{array}$ & $\begin{array}{l}72 \pm 16.14 \\
(50-109)\end{array}$ & $\begin{array}{l}79.3 \pm 21.01 \\
(51-120)\end{array}$ & $\begin{array}{l}71.1 \pm 17.2 \\
(52-112)\end{array}$ & $\begin{array}{l}88.5 \pm 19.07 \\
(52-121)\end{array}$ \\
\hline $\mathbf{6}$ & $\begin{array}{l}\text { Dry weight of } \\
\text { whole plant }(\mathbf{g m})\end{array}$ & $\begin{array}{l}4.3 \pm 0.6 \\
(3.01-5.16)\end{array}$ & $\begin{array}{l}4.4 \pm 1.06 \\
(3.11-6.4)\end{array}$ & $\begin{array}{l}3.9 \pm 0.99 \\
(2.15-6.14)\end{array}$ & $\begin{array}{l}5.9 \pm 1.1 \\
(3.82-7.5)\end{array}$ \\
\hline $\mathbf{7}$ & $\begin{array}{l}\text { Dry weight of } \\
\text { panicle (mg) }\end{array}$ & $\begin{array}{l}1551 \pm 332.7 \\
(990-2130)\end{array}$ & $\begin{array}{l}1754.8 \pm 421.2 \\
(1275-2615)\end{array}$ & $\begin{array}{l}1579.5 \pm 385.5 \\
(1130-2386)\end{array}$ & $\begin{array}{l}1906.3 \pm 432.9 \\
(1139-2814)\end{array}$ \\
\hline $\mathbf{8}$ & $\begin{array}{l}\text { Dry weight of } \\
\text { grains (mg) }\end{array}$ & $\begin{array}{l}1419 \pm 309.6 \\
(993-1988)\end{array}$ & $\begin{array}{l}1600.7 \pm 422.02 \\
(1040-2420)\end{array}$ & $\begin{array}{l}1444.2 \pm 369.2 \\
(1039-2230)\end{array}$ & $\begin{array}{l}1847.4 \pm 400.5 \\
(1160-2791)\end{array}$ \\
\hline $\mathbf{9}$ & $\begin{array}{l}\text { Average weight of } \\
\text { grain }\end{array}$ & $\begin{array}{l}19.75 \pm 0.96 \\
(18.1-21.86)\end{array}$ & $\begin{array}{l}20.19 \pm 0.17 \\
(19.85-20.5)\end{array}$ & $\begin{array}{l}20.30 \pm 1.56 \\
(15.88-22.14)\end{array}$ & $\begin{array}{l}20.9 \pm 0.85 \\
(19.66-23.06)\end{array}$ \\
\hline
\end{tabular}

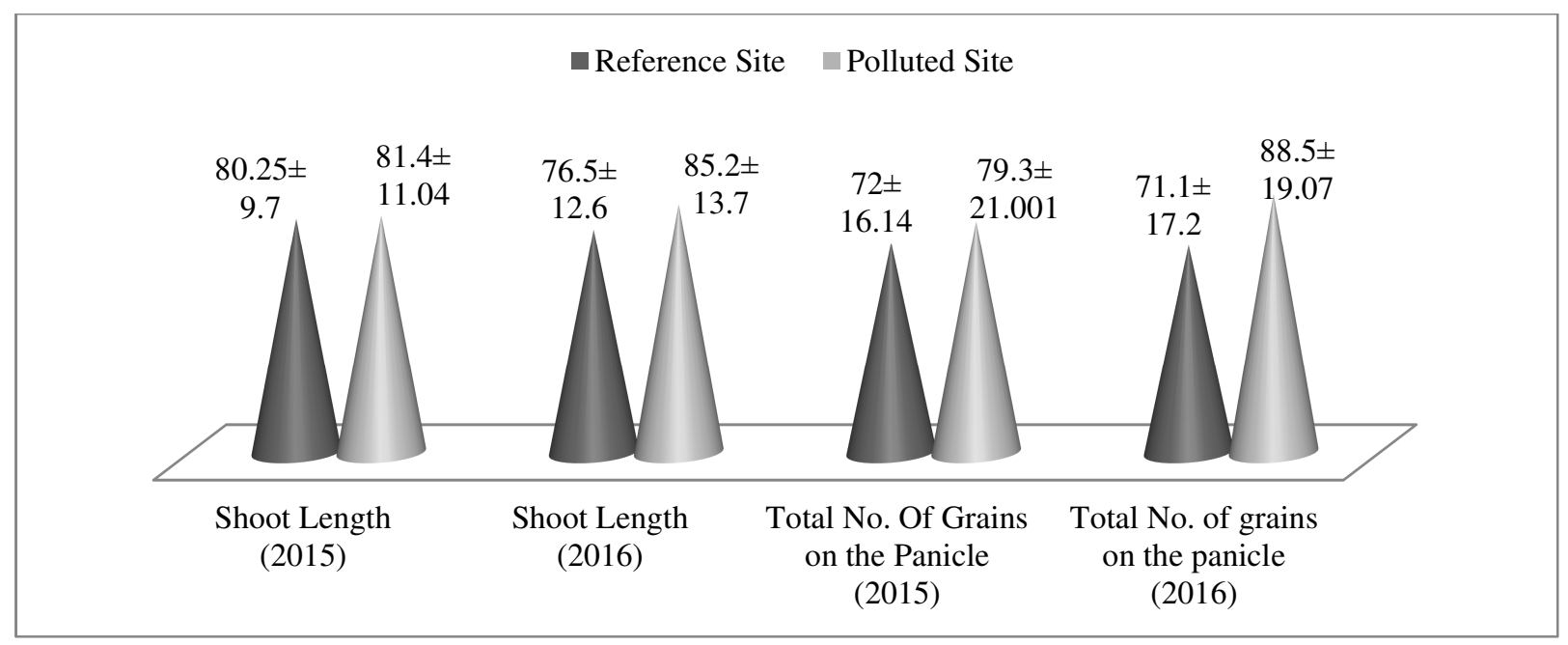

Fig. 1: Impact of combined industrial and sewage effluents on growth and yield of Rice. 


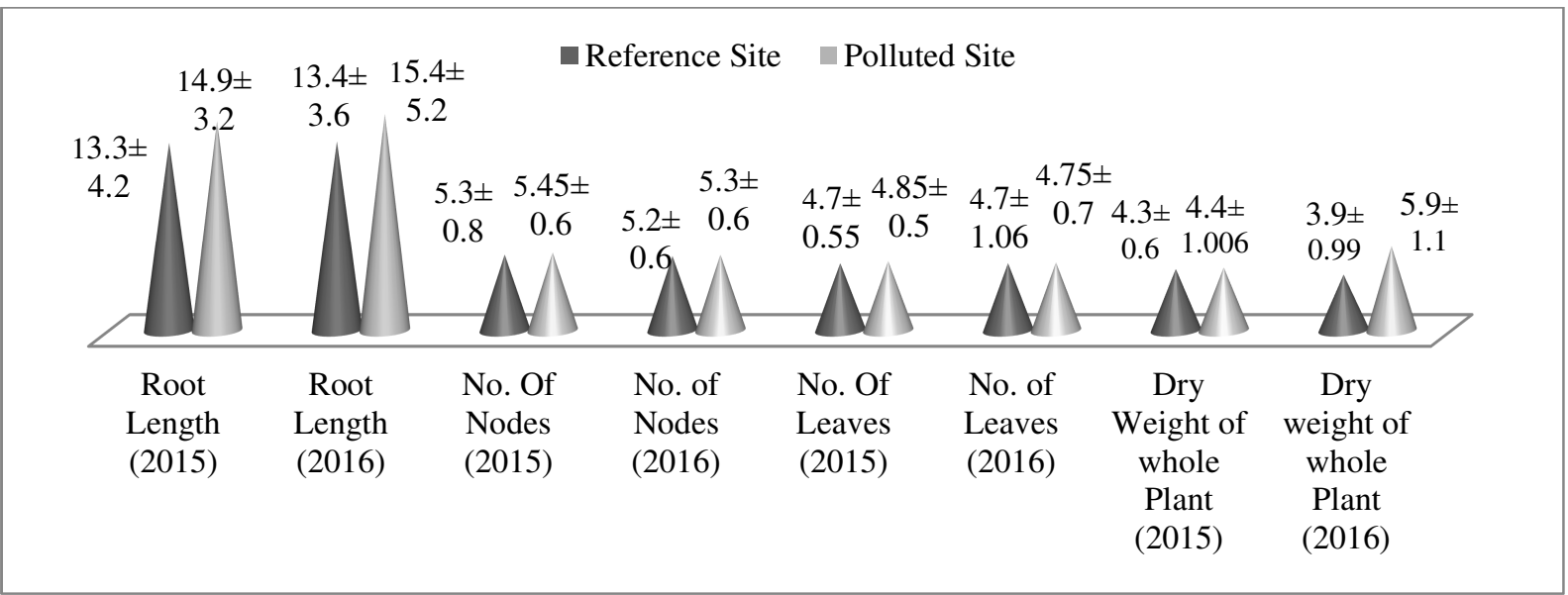

Fig. 2: Impact of combined industrial and sewage effluents on growth of Rice.

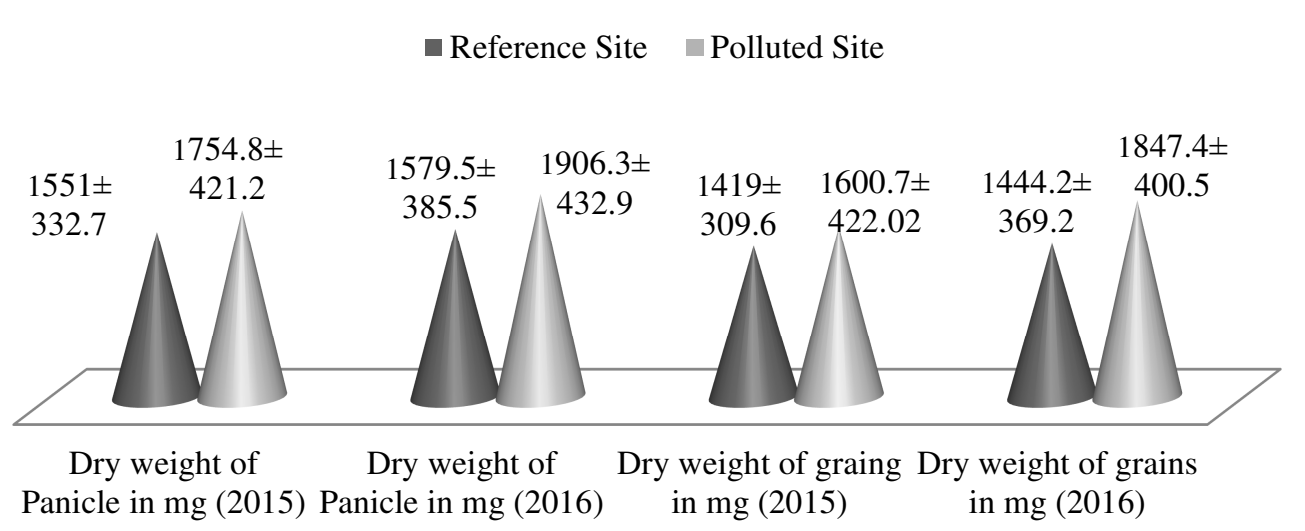

Fig.3: Impact of combined industrial and sewage effluents on yield of Rice.

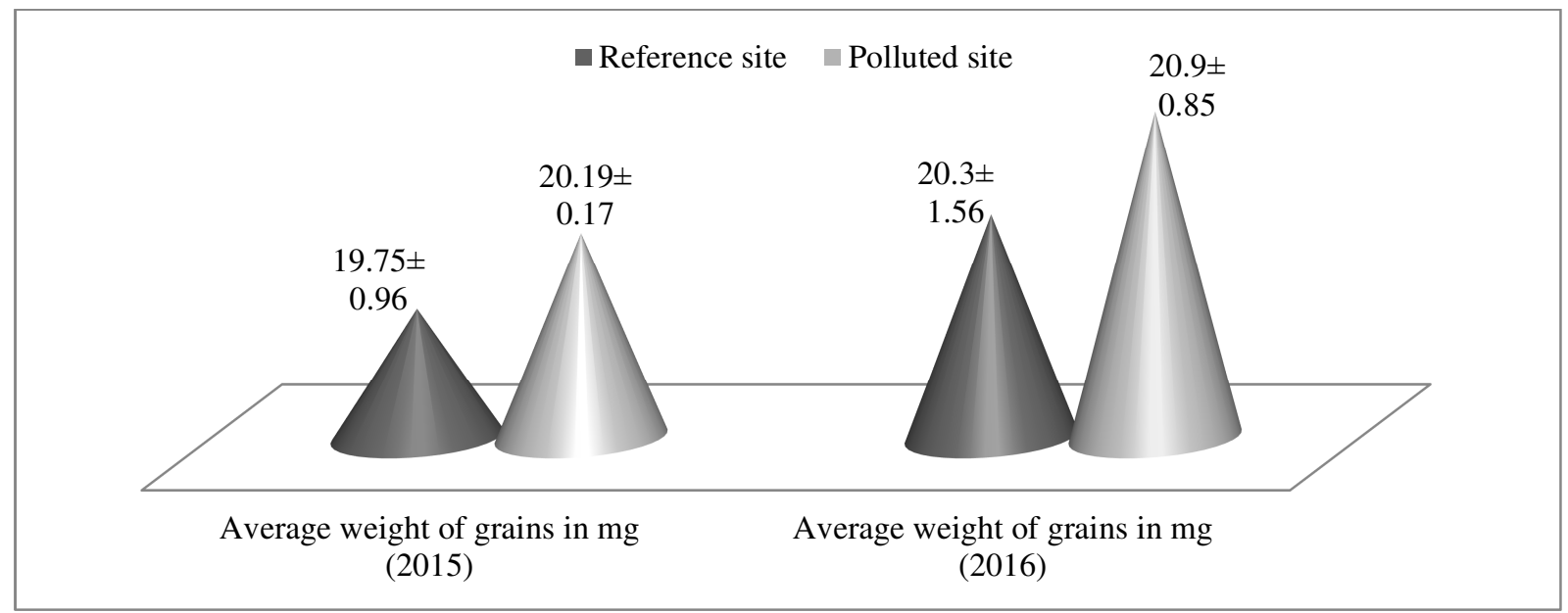

Fig.4: Impact of combined industrial and sewage effluents on yield of Rice.

Environment Conservation Journal 


\section{Sharma and Rampal}

plants (in mg) were also calculated. Finally the average dry weight of each of plant (in $\mathrm{gm}$ ), average dry weight of panicle (in $\mathrm{mg}$ ), and average weight of grain was calculated using Precisa balance XB 120 A with readability of $0.0001-1.0$ gm and LCD display.

\section{Results and Discussion}

The analysis of data revealed that combined sewage and industrial effluent exhibited insignificant ( $>0.05)$ stimulatory effect on shoot length, root length, no. of nodes, no. of leaves, no. of grains on panicle, dry weight of whole plant, dry weight of panicle, dry weight of grains and significant $(\mathrm{p}<0.05)$ stimulatory effect on average weight of grains $(p>0.05)$ of rice during first year study period. This observation is contradictory to the work of Raju et al., (2015) who observed that industrial effluent inhibited the seedling growth of root and shoot of rice. Ali et al., (2015) also reported inhibitory effect of industrial effluent on the crop plants and they suggested that irrespective of the nature, the industrial effluent could be utilized for agricultural crops on proper dilution so as to reduce the lethality of pollutants.

The analysis of data on the yield of rice after irrigation with combined sewage and industrial effluent revealed insignificant $(p>0.05)$ stimulatory effect on root length, no. of nodes, no. of leaves, dry weight of whole plant and average weight of grains and significant $(\mathrm{p}<0.05)$ stimulatory effect on shoot length, no. of grains on the panicle, dry weight of panicle and dry weight of grains during $2^{\text {nd }}$ year study period. This observation supports the work of Pandey and Singh (2015) who reported that fertilizer industrial effluent have a manuarial potential for better crop productivity. Dash (2012) reported that sewage after proper dilution can be used as a potential source of water for seed germination and plant growth in agricultural practices. Al-Dulaimi et al., (2012) also reported that industrial waste water could be well utilized for betterment of agricultural crops in proper dilution to reduce the lethality of pollutants.

\section{References}

Dulaimi, Al-, Ismail, R.I., N.Bt. and Ibrahim, M.H., 2012. The effect of industrial waste water in seed growth rate : A review. International Journal of scientific and research publications. 2(3):1-4.

Ali, S., Akhtar, T. and Alam, M., 2015. The effect of industrial effluents on crop plants : A Review. International journal of research in engineering, IT \& Social Sciences. 5(4):2839.

Bhutiani R., and Ahamad Faheem 2018. Efficiency assessment of Sand Intermittent Filtration Technology for waste water Treatment. International Journal of advance research in science and engineering (IJARSE), 7(03): 503-512.

Bhutiani, R., Khanna,D.R., Shubham and Ahamad Faheem, 2016. Physico-chemical analysis of Sewage water treatment plant at Jagjeetpur, Haridwar, Uttarakhand. Environ. Cons. Jour., 17(3):133-142.

Dash, A. K., 2012. Impact of domestic waste water on seed germination and physiological parameters of Rice and Wheat. IJRRAS. 12(2):280-286.

Pathak, H., Joshi, H.C., Chaudhary, A., Chaudhary, R., Kalra,N., Dwivedi, M.K., 1998. Distillery effluent as soil amendment for wheat and rice. Journal of Indian Society and Soil Science. 46,155-157.

Pathak, H., Joshi, H.C., Chaudhary, A.,Chaudhary, R., Kalra, N., Dwivedi, M.K., 1999. Soil amendment with distillery effluent for wheat and rice cultivation. Water, air and soil pollution.

Pandey, R., and Singh, J., 2015. Effect of industrial waste water irrigation on productivity of wheat crop. International Journal of Environmental Sciences.6 (3):402-409.

Raju, K., Vishnuvardhan, V. and Damodharam T., 2015. Industrial effluents effect on seedling growth of rice and wheat (Oryza Sativa L. And Triticum Vulgare L.) International Journal of Recent Scientific Research. 6(7):4935-4939. 